\title{
BAZY DANYCH W ARCHIWACH PAŃSTWOWYCH. PODSTAWY PRAWNE I WYKORZYSTANIE PRAKTYCZNE
}

\author{
ABSTRACT. Galuba Rafał, Bazy danych w archiwach państwowych. Podstawy prawne $i$ wykorzystanie \\ praktyczne [Databases at national archives. Legal grounds and the practical application] edited by \\ M. Krajewski - „Człowiek i Społeczeństwo”, vol. XXXVI, iss. 2, Poznań 2013, pp. 193-213. Adam \\ Mickiewicz University Press. ISBN 978-83-232-2672-7. ISSN 0239-3271.
}

On the XX turning point and the 21st century with important process occurring in the sphere of functioning of the civil service, including the state archival service, there is a transformation to the global information society, of which providing the free flow for information is a base in an electronic form. The development of electronic administration and becoming widespread are standing the on-line documentation new challenges in collecting, taking over, protecting and making archival materials available before the state archival service. He/she requires not only a computer development of infrastructure and giving the essential provisions essential for the appropriate circulation to the on-line documentation, but also preparing authors and archivists for assessing (of classifying and classifying) of on-line documentation. New tasks are standing in the sphere of disseminating archive information in an electronic form. Legal grounds for creating, the protection and correct practical functioning of databases at national archives consist of two types of provisions: 1) general, which constitutional bases are regulating you and civil rights, principles of operation of administration and public institutions and the process of the computerization of the public sector; 2) detailed of archival law which is resolving principles of archival activity. Databases are playing an important role in the computerization of national archives and disseminating archive information amongst citizens. Still they are essential of action in favour of increasing their effectiveness and the public application as part of the realization of the concept of development of the global information society. Otherwise national archives and their users will be ruled out computer, when existing solutions in implementing electronic administration and managing the on-line documentation will remain on the margin of the worldwide process for the computerization.

Rafał Galuba, Uniwersytet im. Adama Mickiewicza w Poznaniu, Instytut Historii, ul. Św. Marcin 78, 61-809 Poznań, Poland.

Na przełomie XX i XXI wieku ważnym procesem zachodzącym w sferze funkcjonowania administracji publicznej, w tym także państwowej służby archiwalnej, jest transformacja do globalnego społeczeństwa informacyjnego, którego podstawą jest zapewnienie swobodnego przepływu informacji 
$\mathrm{w}$ formie elektronicznej. Wiodącą rolę $\mathrm{w}$ tym procesie odgrywa budowa elektronicznej administracji. Realizacja koncepcji elektronicznej administracji zapewni: 1) przeniesienie niektórych usług publicznych na platformy świadczenia usług elektronicznych, wykorzystujących podpis elektroniczny, 2) standaryzacje procedur załatwiania spraw w organach administracji publicznej, 3) obieg dokumentów elektronicznych, 4) nowe metody dostępu do rejestrów publicznych; 5) rozwój polskich zasobów cyfrowych (np. archiwów i systemów informacji $)^{1}$.

Budowa społeczeństwa informacyjnego jest procesem długotrwałym i wielopłaszczyznowym. W ciągu kilku minionych lat powstały w Polsce podstawy legislacyjne dla równoprawnego funkcjonowania dokumentu elektronicznego z dokumentem papierowym. Niektóre normatywy będą wymagać szybkich nowelizacji. Wiele z nich czeka na uchwalenie. Poważnym wyzwaniem jest także stworzenie infrastruktury teleinformatycznej niezbędnej do upowszechnienia się dokumentu elektronicznego oraz przełamanie nieufności do bezpiecznego podpisu elektronicznego i dokumentu elektronicznego. Należy także zmienić system zarządzania administracji instytucji publicznych, w których dominuje dokumentacja papierowa, aby efektywnie wykorzystać obieg dokumentacji w postaci elektronicznej. Administracja i instytucje publiczne powinny zmienić także swoje zasady funkcjonowania, aby dostosować się do rosnących wymagań ze strony podmiotów gospodarczych i obywateli.

Rozwój administracji elektronicznej oraz upowszechnienie się dokumentacji w postaci elektronicznej stawia nowe wyzwania przed państwową służbą archiwalną $\mathrm{w}$ zakresie gromadzenia, przejmowania, zabezpieczania i udostępniania materiałów archiwalnych. Wymaga nie tylko rozbudowy infrastruktury informatycznej i wydania przepisów niezbędnych dla właściwego obiegu dokumentacji w postaci elektronicznej, lecz również przygotowania twórców i archiwistów do wartościowania (klasyfikowania i kwalifikowania) dokumentacji w postaci elektronicznej. Nowe zadania istnieją też $\mathrm{w}$ sferze upowszechniania informacji archiwalnej $\mathrm{w}$ formie elektronicznej.

W Rzeczypospolitej Polskiej proces budowy społeczeństwa informacyjnego i administracji elektronicznej jest wyraźnie spóźniony w stosunku do najbardziej rozwiniętych państw świata oraz Unii Europejskiej². Podstawy

1 Plan działań na rzecz rozwoju elektronicznej administracji (eGovernment) na lata 2005-2006, Warszawa 2004, s. 2; Strategia kierunkowa rozwoju informatyzacji Polski do roku 2013 oraz perspektywiczna prognoza transformacji społeczeństwa informacyjnego do roku 2020, Warszawa 2005, s. 7-11, 14-19.

2 N. Beagrie, Narodowe inicjatywy w zakresie przechowywania cyfrowego, "Archeion" 2004, t. 107, s. 47-116; K. Schmidt, Prace przygotowawcze do archiwizacji dokumentów elektronicznych - 
prawne niezbędne do informatyzacji sektora publicznego i gospodarki opartej na wiedzy wprowadzono dopiero na początku XXI wieku. Normatywy ukazywały się nieregularnie. Były wyraźnie spóźnione w stosunku do potrzeb $\mathrm{w}$ zakresie nowoczesnego zarządzania administracją publiczną, właściwej obsługi postępowań administracyjnych oraz zaspokajania potrzeb informacyjnych podmiotów gospodarczych, naukowych i obywateli.

Podstawa prawna dla tworzenia, ochrony i prawidłowego funkcjonowania praktycznego baz danych $\mathrm{w}$ archiwach państwowych składa się z dwóch rodzajów przepisów: 1) ogólnych, które regulują podstawy konstytucyjne państwa i prawa obywatela, zasady funkcjonowania administracji i instytucji publicznych oraz proces informatyzacji sektora publicznego; 2) szczegółowych - prawa archiwalnego, które reguluje zasady działalności archiwalnej.

Podstawę legislacyjną społeczeństwa informacyjnego, gospodarki opartej na wiedzy i administracji elektronicznej stanowi Ustawa z dnia 18 września 2001 roku o podpisie elektronicznym (Dz.U. Nr 130, poz. 1450 ze zm.), która wprowadziła do polskiego prawa pojęcie podpisu elektronicznego. Według art. 5 ust. 2 tej ustawy dane w postaci elektronicznej opatrzone bezpiecznym podpisem elektronicznym są równoważne pod względem skutków prawnych dokumentom opatrzonym podpisami własnoręcznymi. Dla budowy administracji elektronicznej najważniejsze znaczenie ma bezpieczny podpis elektroniczny, który musi spełniać trzy warunki: 1) jest przyporządkowany wyłącznie do osoby składającej ten podpis; 2) jest sporządzany za pomocą bezpiecznych urządzeń służących do składania podpisu elektronicznego podlegających wyłącznej kontroli osoby składającej podpis elektroniczny; 3) jest powiązany z danymi, do których został dołączony, w taki sposób, że jakakolwiek późniejsza zmiana tych danych jest rozpoznawalna (art. 3 ust. 2). Ustawodawca dzięki powyższej regulacji dostosował polski system prawny do wymagań stawianych przez administrację elektroniczną i prawo europejskie ${ }^{3}$.

Ustawa z dnia 18 lipca 2002 roku o świadczeniu usług drogą elektroniczną (Dz.U. Nr 144, poz. 1204 ze zm.) zdefiniowała dwa kolejne, ważne dla rozwoju administracji elektronicznej terminy - system teleinformatyczny, który zarządza obiegiem i archiwizowaniem dokumentu elektronicznego, oraz środki komunikacji elektronicznej, które służą do przesyłania dokumen-

doświadczenia australijskie i brytyjskie, "Archeion” 2004, t. 107, s. 117-148; E. Ketelaar, "Cyfrowe $\dot{z} y c i e "$ w archiwum dla ludzi, "Archeion" 2004, t. 107, s. 149-160.

${ }^{3}$ E. Wyrozumska, Elektroniczne oświadczenie woli w ustawie o podpisie elektronicznym i po nowelizacji kodeksu cywilnego, „Przegląd Prawa Handlowego” 2003, nr 8, s. 45; K. Szaniawski, T. Kościelny, Ustawa o podpisie elektronicznym: komentarz, Kraków 2003. 
tów elektronicznych opatrzonych bezpiecznym podpisem elektronicznym, np. między stronami postępowania administracyjnego.

Następnym ważnym normatywem w procesie tworzenia elektronicznej administracji jest Ustawa z dnia 17 lutego 2005 roku o informatyzacji działalności podmiotów realizujących zadania publiczne (Dz.U. Nr 64, poz. 565 ze zm.). Ustawodawca zdefiniował dokument elektroniczny, opierając się wyłącznie na kryteriach techniczno-informatycznych, a nie informatycznym, prawnym i kancelaryjnym, jako stanowiący odrębną całość znaczeniową zbiór danych uporządkowanych $\mathrm{w}$ określonej strukturze wewnętrznej i zapisany na informatycznym nośniku danych (art. 3 ust. 2). Jest to ważny zapis, ponieważ do niego odwołuje się $\mathrm{w}$ art. 1 Ustawa $\mathrm{z}$ dnia 14 lipca 1983 roku o narodowym zasobie archiwalnym i archiwach (Dz.U. $2011 \mathrm{Nr}$ 123, poz. 698 ze zm.; dalej: ustawa archiwalna z 1983 roku) $\mathrm{w}$ związku z definicją materiałów archiwalnych wchodzących w skład narodowego zasobu archiwalnego, które stanowią część dokumentacji przeznaczonej do wieczystego przechowywania.

Rozwój elektronicznej administracji musi uwzględniać również przepisy prawa konstytucyjnego, ochronę praw obywateli, zabezpieczenie informacji niejawnej oraz prawa autorskie. W zakresie ochrony danych osobowych Konstytucja RP z dnia 2 kwietnia 1997 roku (Dz.U. Nr 78, poz. 483 ze zm.) w art. 51 stwierdza, że władze publiczne nie mogą pozyskiwać, gromadzić i udostępniać innych informacji o obywatelach niż niezbędne w demokratycznym państwie prawnym, a obywatel może zostać zobowiązany wyłącznie na podstawie ustawy do ujawniania informacji dotyczących jego osoby. Ponadto każdy obywatel ma konstytucyjne prawo: 1) dostępu do dotyczących go urzędowych dokumentów i zbiorów danych; 2) żądać sprostowania oraz usunięcia informacji nieprawdziwych, niepełnych lub zebranych w sposób sprzeczny z prawem (art. 51) ${ }^{4}$.

Szczegółowe zasady i tryb gromadzenia oraz udostępniania informacji dotyczących obywateli określa Ustawa z dnia 29 sierpnia 1997 roku o ochronie danych osobowych (Dz.U. Nr 133, poz. 883 ze zm.). Na jej podstawie każdy obywatel ma prawo do ochrony dotyczących go danych osobowych (art. 1 ust. 1) $)^{5}$. Przetwarzanie danych osobowych, np. w bazach dany lub systemie teleinformatycznym, może mieć miejsce ze względu na: 1) dobro publiczne, 2) dobro osoby, której dane dotyczą, 3) dobro osób trzecich (art. 1 ust. 2). Do przestrzegania zasad ochrony danych osobowych sa zobowiązane: 1) państwowa służba archiwalna, 2) twórcy materiałów archiwalnych wchodzących w skład państwowego zasobu archiwalnego,

\footnotetext{
${ }^{4}$ S. Sagan, Prawo konstytucyjne Rzeczypospolitej Polskiej, Warszawa 2001, s. 78.

${ }^{5} \mathrm{Za}$ dane osobowe uważa się każdą informację dotyczącą osoby fizycznej pozwalającą na określenie tożsamości tej osoby (art. 6 ust. 1).
} 
3) twórcy dokumentacji osobowo-płacowej, 4) instytucje przechowujące dokumentację płacowo-osobową, 5) inni twórcy dokumentacji nie archiwalnej, w której występują dane osobowe, 6) podmioty realizujące zadania publiczne oraz przetwarzające dane osobowe $\mathrm{w}$ związku z działalnością zarobkową, zawodową lub dla realizacji celów statutowych (art. 3).

Istotny wpływ na zarządzanie dokumentacją i materiałami archiwalnymi ma ustawodawstwo ogólnopaństwowe dotyczące praw obywatelskich i zasad dostępu do informacji publicznej. Ustawa z dnia 6 września 2001 roku o dostępie do informacji publicznej (Dz.U. Nr 112, poz. 1198 ze zm.) daje obywatelowi prawo do bezpłatnego udostępniania informacji publicznej, która nie została zamieszczona w Biuletynie Informacji Publicznej. Odmowa udostępnienia informacji publicznej przez organ władzy publicznej następuje $\mathrm{w}$ drodze decyzji, zgodnie $\mathrm{z}$ Kodeksem postępowania administracyjnego (Ustawa z dnia 14 czerwca 1960 roku, Dz.U. Nr 30, poz. 168, art. 16) ${ }^{6}$.

Na podstawie Ustawy z dnia 4 lutego 1994 roku o prawie autorskim i prawach pokrewnych (Dz.U. $2006 \mathrm{Nr}$ 90, poz. 631 ze zm.) przedmiotem prawa autorskiego jest każdy przejaw działalności twórczej o indywidualnym charakterze, ustalony $\mathrm{w}$ jakiejkolwiek postaci, niezależnie od wartości, przeznaczenia i sposobu wyrażenia, w tym również bazy danych spełniające cechy utworu (art. 1 i 3$)^{7}$.

Według art. 1 Ustawy z dnia 27 lipca 2001 roku o ochronie baz danych (Dz.U. Nr 128, poz. 1402 ze zm.) ochronie określonej w przepisach podlegają bazy danych ${ }^{8}$, z wyłączeniem baz danych spełniających cechy utworu określone w Ustawie z dnia 4 lutego 1994 roku o prawie autorskim i prawach pokrewnych.

Bazy danych i systemy teleinformatyczne używane przez administracje publiczną bardzo często, zwłaszcza $\mathrm{w}$ podmiotach nadzorowanych przez archiwa wyodrębnione, zawierają informacje niejawne ${ }^{9}$. Zasady klasyfiko-

\footnotetext{
${ }^{6}$ Sądem właściwym do orzekania w powyższych sprawach jest sąd rejonowy właściwy ze względu na siedzibę podmiotu, który odmówił udostępnienia informacji publicznej (art. 22). T.R. Aleksandrowicz, Komentarz do ustawy o dostępie do informacji publicznej. Stan prawny na 2 stycznia 2008 roku, Warszawa 2008, s. 248-251, 260-263.

${ }^{7}$ Nie stanowią przedmiotu prawa autorskiego: 1) akty normatywne lub ich urzędowe projekty, np. kancelaryjne i archiwalne, 2) urzędowe dokumenty, materiały, znaki i symbole, 3) opublikowane opisy patentowe lub ochronne, 4) proste informacje prasowe (art. 4).

8 Według art. 2.1 baza danych oznacza zbiór danych lub jakichkolwiek innych materiałów i elementów zgromadzonych według określonej systematyki lub metody, indywidualnie dostępnych $\mathrm{w}$ jakikolwiek sposób, w tym środkami elektronicznymi, wymagający istotnego, co do jakości lub ilości, nakładu inwestycyjnego w celu sporządzenia, weryfikacji lub prezentacji jego zawartości.

${ }^{9}$ W. Janowski, Archiwa państwowe wobec problemu akt niejawnych, "Teki Archiwalne” 2000, t. 5, s. 59-66.
} 
wania informacji niejawnej i jej ochronę reguluje Ustawa $\mathrm{z}$ dnia 5 sierpnia 2010 roku o ochronie informacji niejawnych (Dz.U. Nr 182, poz. 1228) ${ }^{10}$. Od 2 stycznia 2011 roku dokumentację zawierającą wyłącznie informacje niejawne11 dzieli się według klauzuli tajności na: 1) "ściśle tajne", 2) „tajne", 3) „poufne” i 4) „zastrzeżone” (art. 5). Podstawową komórką organizacyjną nadzorującą obieg informacji niejawnej oraz jej ochronę w jednostce organizacyjnej jest kancelaria tajna usytuowana w strefie bezpieczeństwa.

$\mathrm{Na}$ podstawie Rozporządzenia Rady Ministrów z dnia 7 grudnia 2011 roku w sprawie organizacji i funkcjonowania kancelarii tajnych oraz sposobu i trybu przetwarzania informacji niejawnych (Dz.U. Nr 276, poz. $1631)^{12}$ kierownik jednostki organizacyjnej, w której są przetwarzane informacje niejawne o klauzuli „tajne” lub „ściśle tajne”, musi utworzyć kancelarię tajną (lub więcej niż jedną kancelarię tajną) oraz zatrudnić jej kierownika. Może również wyrazić zgodę na przetwarzanie $\mathrm{w}$ kancelarii tajnej informacji niejawnych o klauzuli „poufne” lub „zastrzeżone”. W normatywie uwzględniono również postępowanie z dokumentami elektronicznymi i systemami teleinformatycznymi zawierającymi informacje niejawne. Ustawodawca dopuścił również możliwość prowadzenia w kancelarii tajnej ewidencji $\mathrm{w}$ formie elektronicznego rejestru dokumentów w systemie teleinformatycznym spełniającym określone wymagania w zakresie: rozliczalności, niezaprzeczalności, integralności i dostępności. Zalecił również dodatkowe zabezpieczenie pomieszczeń, w których znajdują się kancelarie tajne lub będą przechowywane dokumenty zawierające informacje niejawne. Zgodnie z § 10 dokument, który nie jest przewidziany do dalszego wykorzystywania praktycznego, o ile nie stanowi materiału archiwalnego w rozumieniu art. 1 ustawy archiwalnej z 1983 roku, może zostać zniszczony, z zastrzeżeniem przepisów o narodowym zasobie archiwalnym i archiwach. Powinno się go zniszczyć w taki sposób, aby niemożliwe było całkowite lub częściowe odtworzenie jego treści. Dlatego niezależnie od tego, czy dokumenty elektroniczne lub bazy danych zawierają informacje niejawne,

${ }^{10}$ W latach 1984-1999 podstawę prawną jej ochrony stanowiła Ustawa z dnia 14 grudnia 1982 roku o ochronie tajemnicy państwowej i służbowej (Dz.U. Nr 40, poz. 271 ze zm.), w latach 1999-2010 - Ustawa z dnia 22 stycznia 1999 roku o ochronie informacji niejawnych (Dz.U. 2005 Nr 196, poz. 1631 ze zm.).

11 Według art. 1 ust. 1 informacje niejawne to informacje, których nieuprawnione ujawnienie spowodowałoby lub mogłoby spowodować szkody dla Rzeczypospolitej Polskiej albo byłoby z punktu widzenia jej interesów niekorzystne, także w trakcie ich opracowywania oraz niezależnie od formy i sposobu ich wyrażania.

12 Rozporządzenie Prezesa Rady Ministrów z dnia 27 kwietnia 2011 roku w sprawie przygotowania i przeprowadzania kontroli stanu zabezpieczenia informacji niejawnych (Dz.U. Nr 93, poz. 541), Rozporządzenie Prezesa Rady Ministrów z dnia 28 grudnia 2010 roku w sprawie wzorów poświadczeń bezpieczeństwa (Dz.U. 2010 Nr 258, poz. 1752). 
czy ich nie zawierają, należy opracować skuteczne procedury ich niszczenia, które uniemożliwią nieuprawniony dostęp lub ich powtórne wykorzystanie.

Rozporządzenie Prezesa Rady Ministrów z dnia 20 lipca 2011 roku $\mathrm{w}$ sprawie podstawowych wymagań bezpieczeństwa teleinformatycznego (Dz.U. Nr 159, poz. 948) określa najważniejsze wymagania bezpieczeństwa, jakim powinny odpowiadać systemy teleinformatyczne służące do przetwarzania i przechowywania dokumentacji elektronicznej zawierającej informacje niejawne. Dlatego ich ochrona przed nieuprawnionym dostępem, zasady tworzenia i przechowywania kopii zapasowych, procedury postępowania $\mathrm{w}$ sytuacjach kryzysowych, $\mathrm{w}$ tym $\mathrm{w}$ przypadkach awarii elementów systemu teleinformatycznego, oraz przydzielanie użytkownikom uprawnień do pracy w systemie teleinformatycznym są szczególnie ważne. $Z$ punktu widzenia archiwizowania dokumentacji bardzo istotne jest postanowienie, że informatyczne nośniki danych przeznaczone do przetwarzania informacji niejawnych obejmuje się ochroną od momentu oznaczenia nośnika klauzulą tajności aż do trwałego usunięcia danych na nim zapisanych oraz zniesienia klauzuli tajności albo do momentu jego zniszczenia ${ }^{13}$.

Informacje niejawne nie są jedynymi tajemnicami prawnie chronionymi, które muszą być przestrzegane przez państwową służbę archiwalną podległą naczelnemu dyrektorowi archiwów państwowych. Archiwa gromadzą materiały archiwalne ze specjalnie wyselekcjonowanych państwowych i samorządowych jednostek organizacyjnych, dotyczące różnych aspektów działalności państwa i obywateli oraz chronione tajemnicami zawodowymi. Ich zbiór jest bardzo rozbudowany. Do najważniejszych należą tajemnice: 1) przedsiębiorstwa, 2) handlowa, 3) bankowa, 4) statystyczna, 5) kontroli państwowej, 6) adwokacka, radcowska, notarialna i komornika sądowego, 7) ksiąg rachunkowych, 8) lekarska, 9) skarbowa, 10) dziennikarska, 11) geologiczna i geodezyjna, 12) postępowania administracyjnego i postępowania karnego, 13) akt stanu cywilnego, 14) korespondencji, 15) czynności operacyjno-rozpoznawczych, 16) informacji kryminalnej, 17) ochrony życia prywatnego i rodzinnego oraz innych dóbr osobistych, 18) ubezpieczeń ${ }^{14}$. Ochrona innych tajemnic ustawowo chronionych, podobnie jak ochrona informacji niejawnych, nie może stanowić podstawy do wyłączenia określonych dokumentacji i materiałów archiwalnych w formie elektro-

${ }^{13}$ Zgodnie z Rozporządzeniem Ministra Spraw Wewnętrznych i Administracji z dnia 30 października 2006 roku w sprawie szczegółowego sposobu postępowania z dokumentami elektronicznymi, Archiwa. Przepisy prawne (2000-2007), wybór i oprac. R. Galuba, Poznań 2007 (dalej: APP), s. 257-266.

${ }^{14}$ R. i M. Taradejna, Dostęp do informacji publicznej a prawna ochrona informacji dotyczacych działalności gospodarczej, społecznej i zawodowej oraz życia prywatnego, Torun 2003, s. 25-109. 
nicznej z udostępnienia, z wyjątkiem wypadków niezbędnych w demokratycznym państwie prawa.

Działalność archiwalna obejmuje: 1) gromadzenie, ewidencję, przechowywanie, opracowywanie, zabezpieczanie i udostępnianie materiałów archiwalnych, 2) prowadzenie działalności informacyjnej i popularyzatorskiej, 3) wydawanie urzędowych zaświadczeń, odpisów i poświadczeń (archiwa państwowe jako urzędy administracji rządowej niezespolonej - urzędy wiary publicznej). Podstawę prawną działalności archiwalnej stanowi ustawa archiwalna z 1983 roku. Na podstawie art. 22 ust. 1 tejże ustawy archiwa państwowe, które prowadzą działalność archiwalną w zakresie państwowego zasobu archiwalnego, dzielą się na: 1) archiwa państwowe podległe naczelnemu dyrektorowi archiwów państwowych, 2) archiwa wyodrębnione (do 2007 roku archiwa państwowe wyodrębnione15), np. Sejmu RP, Senatu RP, Prezydenta RP i Rady Ministrów, 3) archiwa zakładowe państwowych i samorządowych jednostek organizacyjnych. Archiwa wyodrębnione są niezależne od Ministra Kultury i Dziedzictwa Narodowego, który od 2005 roku sprawuje nadzór nad narodowym zasobem archiwalnym za pośrednictwem naczelnego dyrektora archiwów państwowych ${ }^{16}$. Ustawodawca zgodził się na wyłączenie spod kontroli naczelnego dyrektora archiwów państwowych bardzo ważnej części materiałów archiwalnych wchodzących w skład państwowego zasobu archiwalnego.

Przepisy wykonawcze do ustawy archiwalnej z 1983 roku, a zwłaszcza Rozporządzenie Ministra Kultury z dnia 16 września 2002 roku w sprawie postępowania $\mathrm{z}$ dokumentacją, zasad jej klasyfikowania i kwalifikowania oraz zasad i trybu przekazywania materiałów archiwalnych do archiwów państwowych (Dz.U. Nr 167, poz. 1375) oraz przepisy dotyczące szczegółowych zasad postępowania $\mathrm{z}$ określonymi rodzajami dokumentacji nie były dostosowane do klasyfikowania i kwalifikowania oraz zasad i trybu przekazywania materiałów archiwalnych $\mathrm{w}$ postaci elektronicznej do archiwów państwowych oraz ich przechowywania w dłuższym czasie. Według $§ 17$ tej ustawy materiały archiwalne utrwalone na innych nośnikach (np. cyfrowych) należy uporządkować i przygotować do przekazania w sposób uzgodniony z dyrektorem właściwego archiwum państwowego.

Wprowadzenie dokumentu elektronicznego do administracji publicznej wymusiło konieczność opracowania zasad gromadzenia materiałów archiwalnych $\mathrm{w}$ tej formie. W ustawie archiwalnej z 1983 roku w niedostateczny

${ }^{15} \mathrm{Na}$ podstawie art. 1 pkt 9 Ustawy z dnia 2 marca 2007 roku o zmianie ustawy o narodowym zasobie archiwalnym i archiwach oraz ustawy Kodeks pracy, APP, s. 280-281.

${ }^{16}$ Na podstawie § 1 Rozporządzenia Rady Ministrów z dnia 31 października 2005 roku zmieniającego rozporządzenie w sprawie utworzenia Ministerstwa Kultury (Dz.U. Nr 220, poz. 1885). 
sposób uwzględniono przepisy dotyczące gromadzenia dokumentacji elektronicznej, w tym prowadzenia spraw urzędowych w systemach teleinformatycznych do elektronicznego zarządzania dokumentacją. Zgodnie ze znowelizowanym w 1997 roku art. 5 minister właściwy do spraw informatyzacji17, po zasięgnięciu opinii naczelnego dyrektora archiwów państwowych, miał określić $\mathrm{w}$ drodze rozporządzenia szczegółowy sposób postępowania $\mathrm{z}$ dokumentami elektronicznymi u twórców materiałów archiwalnych ${ }^{18}$, w szczególności zasady ewidencjonowania, klasyfikowania i kwalifikowania dokumentów elektronicznych oraz zasady i tryb ich brakowania, uwzględniając potrzebę zapewnienia integralności dokumentów elektronicznych i długotrwałego ich przechowywania (ust. 2a i 2b) ${ }^{19}$. Minister właściwy do spraw informatyzacji, w porozumieniu z ministrem właściwym do spraw kultury i ochrony dziedzictwa narodowego, na wniosek naczelnego dyrektora archiwów państwowych, miał określić w drodze rozporządzenia wymagania techniczne, jakim powinny odpowiadać formaty zapisu $\mathrm{i}$ informatyczne nośniki danych (w rozumieniu przepisów Ustawy z dnia 17 lutego 2005 roku o informatyzacji działalności podmiotów realizujących zadania publiczne) przekazywanych do archiwów państwowych materiałów archiwalnych utrwalonych na informatycznych nośnikach danych (ust. 2c) ${ }^{20}$. Powyższe kwestie $\mathrm{w}$ odniesieniu do archiwów wyodrębnionych mieli uregulować ministrowie i inne organy nadzorujące archiwa wyodrębnione (art. 5 ust. 3 pkt 1-7 $)^{21}$. Na podstawie delegacji ustawowej zawartej w art. 5 ust. 2a-2c Minister Spraw Wewnętrznych i Administracji wydał szczegółowe przepisy dotyczące zasad postępowania z dokumentem elektronicznym.

Według Rozporządzenia Ministra Spraw Wewnętrznych i Administracji z dnia 30 października 2006 roku w sprawie niezbędnych elementów struktury dokumentów elektronicznych (Dz.U. Nr 206, poz. 1517) dokumenty elektroniczne powinny spełniać jeszcze dwa warunki: 1) być sporządzone

17 Na podstawie art. 12a Ustawy z dnia 4 września 1997 roku o działach administracji rządowej (Dz.U. Nr 173, poz. 1218 ze zm.).

$18 \mathrm{Na}$ podstawie art. 49 pkt 2 Ustawy z dnia 24 lipca 1998 roku o zmianie niektórych ustaw określających kompetencje organów administracji publicznej - w związku z reformą ustrojową państwa (Dz.U. Nr 106, poz. 668).

${ }^{19}$ Na podstawie art. 37 pkt 2 lit. a Ustawy z dnia 17 lutego 2005 roku o informatyzacji działalności podmiotów realizujących zadania publiczne, APP, s. 27.

${ }^{20} \mathrm{Na}$ podstawie: ibidem.

${ }^{21} \mathrm{Na}$ podstawie art. 37 pkt 2 lit. b Ustawy z dnia 17 lutego 2005 roku o informatyzacji działalności podmiotów realizujących zadania publiczne, APP, s. 27-28. Zob. Zarządzenie Nr 12 Ministra Obrony Narodowej z dnia 12 marca 2010 roku w sprawie szczególnego sposobu organizacji kancelarii tajnych oraz innych niż kancelaria tajna komórek organizacyjnych odpowiedzialnych za rejestrowanie, przechowywanie, obieg i udostępnianie materiałów niejawnych, stosowania środków ochrony fizycznej oraz obiegu informacji niejawnych (Dz. Urz. MON Nr 5, poz. 49). 
$\mathrm{w}$ formacie $\mathrm{XML}$ 22; 2) być zapisywane $\mathrm{w}$ strukturze umożliwiającej automatyczne wyodrębnienie treści dokumentu oraz poszczególnych metadanych ${ }^{23}$.

Rozporządzenie Ministra Spraw Wewnętrznych i Administracji z dnia 30 października 2006 roku w sprawie szczegółowego sposobu postępowania z dokumentami elektronicznymi (Dz.U. Nr 206 poz. 1518) zawiera systematykę dokumentów elektronicznych świadczących o wykonywaniu działalności podmiotów, które podlegają ewidencjonowaniu $\mathrm{w}$ systemie teleinformatycznym - "dokumenty ewidencjonowane". Dzielą się one na: 1) materiały archiwalne, 2) inne dokumenty niestanowiące materiałów archiwalnych, które mogą podlegać brakowaniu po upływie okresu ich przechowywania - „dokumentacja nie archiwalna”. Dokumenty elektroniczne, które nie podlegają ewidencjonowaniu w systemie teleinformatycznym, są usuwane $\mathrm{w}$ sposób przyjęty $\mathrm{w}$ danym podmiocie. Zgodnie $\mathrm{z} \S 6$ postępowanie $\mathrm{z}$ dokumentami ewidencjonowanymi i metadanymi prowadzi się przy użyciu systemu teleinformatycznego, który powinien spełniać następujące wymagania: 1) zapewnić integralność treści dokumentów i metadanych; 2) zabezpieczyć przed wprowadzaniem zmian $\mathrm{w}$ dokumentach spraw załatwionych oraz ich usunięciem z systemu; 3) zapewnić stały i skuteczny dostęp do dokumentów oraz ich wyszukiwanie; 4) zapewnić kontrolę dostępu poszczególnych użytkowników; 5) zapewnić odtworzenie przebiegu załatwiania i rozstrzygania spraw; 6) wspomagać czynności związane z klasyfikowaniem i kwalifikowaniem dokumentów, brakowaniem dokumentacji niearchiwalnej oraz przekazaniem materiałów archiwalnych i ich metadanych do archiwum państwowego; 7) umożliwić przesyłanie dokumentów do innych systemów teleinformatycznych. System teleinformatyczny, w którym są dodatkowo przetwarzane dokumenty zawierające informacje niejawne, musi ponadto spełniać wymagania określone w Ustawie z dnia 5 sierpnia 2010 roku o ochronie informacji niejawnych. Na podstawie $\S 7$ system teleinformatyczny pełni dla dokumentów ewidencjonowanych funkcję archiwum zakładowego lub składnicy akt. W przypadku dokumentacji mieszanej: tradycyjnej - papierowej lub poza aktowej oraz elektronicznej, część tradycyjna jest przechowywana $\mathrm{w}$ archiwum zakładowym lub składnicy akt, część elektroniczna w systemie teleinformatycznym. Jednostki organizacyjne znajdujące się pod nadzorem archiwalnym muszą zapewnić nadzór nad prawidłowością: 1) funkcjonowania systemu teleinformatycznego, 2) opracowania i aktualizowania procedur przechowywania dokumentów elektronicznych w czasie nie krótszym niż 10 lat oraz przeprowa-

${ }^{22}$ XML - Extensible Markup Language.

${ }^{23}$ APP, s. 255-256. 
dzanie ich corocznych kontroli, 3) przygotowania i realizacji planów przeniesienia dokumentów ewidencjonowanych na nowe informatyczne nośniki danych ${ }^{24}$.

Postępowanie z dokumentami ewidencjonowanymi i metadanymi prowadzi się przy użyciu systemu teleinformatycznego.

Rozporządzenie Ministra Spraw Wewnętrznych i Administracji z dnia 2 listopada 2006 roku w sprawie wymagań technicznych formatów zapisu i informatycznych nośników danych, na których utrwalono materiały archiwalne przekazywane do archiwów państwowych (Dz.U. Nr 206, poz. 1519) w § 1 określa wymagania techniczne, jakim powinny odpowiadać formaty zapisu i informatyczne nośniki danych $\mathrm{w}$ rozumieniu przepisów Ustawy z dnia 17 lutego 2005 roku o informatyzacji działalności podmiotów realizujących zadania publiczne, przekazywanych do archiwów państwowych materiałów archiwalnych utrwalonych na informatycznych nośnikach danych.

Twórcy materiałów archiwalnych wchodzących w skład państwowego zasobu archiwalnego na podstawie art. 5 i 6 ustawy archiwalnej z 1983 roku oraz przepisów wykonawczych obowiązani byli do klasyfikowania i kwalifikowania powstającej i narastającej w nich dokumentacji bez względu na jej postać (papierowa, elektroniczna itp.). Każdy podmiot, niezależnie od wdrożenia systemu elektronicznego zarządzania dokumentacją i digitalizowania otrzymywanej $\mathrm{w}$ postaci papierowej dokumentacji, był zobowiązany do równoległego wykonywania tych samych czynności kancelaryjnych w stosunku do dokumentacji w postaci papierowej. Przepisy wykonawcze wydane na podstawie art. 5 ust. 2 przewidują bowiem obowiązek porządkowania dokumentacji $\mathrm{w}$ postaci papierowej wyłącznie $\mathrm{w}$ układzie według spraw i teczek rzeczowych. Niezbędne było wydanie nowych przepisów wykonawczych dotyczących zasad klasyfikowania i kwalifikowania dokumentacji, aby uniknąć konieczności prowadzenia spraw urzędowych równolegle $\mathrm{w}$ systemie tradycyjnym i systemie teleinformatycznym do elektronicznego zarządzania dokumentacją ${ }^{25}$.

Brak nowych przepisów nie ułatwia: 1) gromadzenia, zarządzania i przechowywania dokumentacji $\mathrm{w}$ postaci elektronicznej, 2) załatwiania spraw w systemie elektronicznego zarządzania dokumentacją EZD, 3) upraszczania zasad postępowania $\mathrm{z}$ dokumentacją $\mathrm{w}$ przypadku współistnienia systemów EZD i systemu zarządzania dokumentacją na nośnikach tradycyjnych (papierowych). Niezbędna jest nie tylko zmiana upoważnienia

\footnotetext{
${ }^{24}$ Rozporządzenie Ministra Spraw Wewnętrznych i Administracji z dnia 30 października 2006 roku w sprawie szczegółowego sposobu postępowania z dokumentami elektronicznymi, APP, s. 257-266.

${ }^{25}$ Projekt założeń projektu ustawy o zmianie ustawy o narodowym zasobie archiwalnym i archiwach z dnia 9 lutego 2011 roku.
} 
i aktu normatywnego wykonawczego, lecz również przeniesienie niektórych postanowień z przepisów wykonawczych do ustawy archiwalnej z 1983 roku.

Prezes Rady Ministrów w 2011 roku ogłosił akt normatywny regulujący zasady postępowania $\mathrm{z}$ dokumentacją $\mathrm{w}$ systemie EZD, co niewątpliwie wpłynie na przyspieszenie procesu informatyzacji sektora publicznego oraz zwiększy liczbę dostępnych usług $\mathrm{w}$ postaci elektronicznej. Jest to podstawa kompleksowego załatwiania spraw elektronicznie w ramach systemów teleinformatycznych, poprzez dopuszczenie różnorodnych metod przechowywania powstającej równolegle dokumentacji papierowej, w zależności od stopnia zaawansowania systemów EZD. Czynności kancelaryjne mogą być od 18 stycznia 2011 roku wykonywane w systemie: 1) tradycyjnym, 2) teleinformatycznym do EZD. Do czasu wydania ramowych przepisów nie było dostatecznych podstaw prawnych do prowadzenia spraw w systemie elektronicznym. Przepisy dają kierownikowi komórki organizacyjnej prawo wyboru dwóch sposobów postępowania z dokumentacją ${ }^{26}$.

Prezes Rady Ministrów (dla niektórych archiwów wyodrębnionych) oraz organy zarządzające lub nadzorujące archiwa wyodrębnione otrzymali prawo określenia dla dokumentacji elektronicznej: 1) sposobu klasyfikowania i kwalifikowania ze względu na okresy jej przechowywania, 2) zasad: a) jej przekazywania do Centralnego Archiwum Wojskowego dla dokumentacji stanowiącej materiał archiwalny, b) brakowania, 3) wymagań technicznych, jakim powinny odpowiadać formaty zapisu i informatyczne nośniki danych do jej zapisu - z uwzględnieniem potrzeby jej ochrony przed nieuprawnionym dostępem ${ }^{27}$.

Uzupełnieniem przepisów ogólnych są normatywy wewnętrzne. Zarządzenia regulujące wewnętrzną strukturę archiwów państwowych zawierają następujące zadania dla komórki organizacyjnej do spraw informatyzacji: 1) administrowanie sieciami komputerowymi i bazami danych, 2) programowanie, organizowanie i koordynacja działalności informacyjnej, 3) czuwanie nad bezpieczeństwem i archiwizacją danych ${ }^{28}$, 4) weryfikacja stanu zabezpieczenia kopii cyfrowych, 5) udostępnianie dokumentów drogą elektroniczną, 6) realizacja polityki bezpieczeństwa $\mathrm{w}$ zakresie przetwarzania danych w postaci elektronicznej, 7) nadzór nad elektronicznym obiegiem

26 Rozporządzenie Prezesa Rady Ministrów z dnia 18 stycznia 2011 roku w sprawie instrukcji kancelaryjnej, jednolitych rzeczowych wykazów akt oraz instrukcji w sprawie organizacji i zakresu działania archiwów zakładowych (Dz.U. Nr 14, poz. 67).

$27 \mathrm{Na}$ podstawie art. 1 pkt 1 lit. b Ustawy z dnia 2 marca 2007 roku o zmianie ustawy o narodowym zasobie archiwalnym i archiwach oraz ustawy Kodeks pracy, APP, s. 277-278.

28 Stosownie do wymogów Ustawy o ochronie danych osobowych z dnia 29 sierpnia 1997 roku oraz Rozporządzenia Ministra Spraw Wewnętrznych i Administracji z dnia 23 czerwca 1998 roku (Dz.U. Nr 80, poz. 521). 
dokumentacji w archiwum, 8) współdziałanie z innymi komórkami organizacyjnymi $\mathrm{w}$ sprawie przejmowania i przechowywania $\mathrm{w}$ zasobie archiwum materiałów archiwalnych i pomocy ewidencyjnych wytwarzanych $\mathrm{w}$ formie elektronicznej29.

Zmiany ustrojowe rozpoczęte w 1989 roku i budowa społeczeństwa obywatelskiego nie wpłynęły $w$ znaczący sposób na ułatwienie dostępu obywateli do informacji zawartych $\mathrm{w}$ materiałach archiwalnych, także $\mathrm{w}$ formie baz danych i dokumentu elektronicznego, należących do państwowego zasobu archiwalnego. Nadal występuje wiele ograniczeń prawnych $^{30}$, administracyjnych ${ }^{31}$ i organizacyjnych ${ }^{32}$, które utrudniają obywatelom dostęp do państwowego zasobu archiwalnego przechowywanego w państwowej sieci archiwalnej.

W archiwach państwowych dokumentację i materiały archiwalne na potrzeby określone w art. 16 ustawy archiwalnej z 1983 roku dla potrzeb nauki, kultury, techniki i gospodarki udostępniania się do celów: 1) służbowych, 2) naukowo-badawczych, 3) publicystycznych, 4) innych (np. edukacyjnych), 5) obywateli.

${ }^{29}$ Zob.: 1) Regulamin Organizacyjny Archiwum Państwowego w Katowicach z 27 lutego 2008 roku, http:/ / bip.ap.gov.pl/dokument.php [dostęp: 12.11.2012]; 2) Regulamin Organizacyjny Archiwum Państwowego w Lublinie z 29 grudnia 2006 roku, http://bip.ap.gov.pl/ dokument.php [dostęp: 12.11.2012]; 3) Regulamin organizacyjny Archiwum Państwowego w Krakowie z 20 lutego 2012 roku, http://www.wrotamalopolski.pl/root_BIP/ [dostęp: 12.11.2012]; 4) Regulamin organizacyjny Archiwum Państwowego we Wrocławiu z 11 stycznia 2012 roku, http://bip.ap.gov.pl/dokument.php [dostęp: 12.11.2012]; 5) Regulamin Organizacyjny Archiwum Państwowego m.st. Warszawy z 27 stycznia 2012 roku, http://bip.ap. gov.pl/dokument.php [dostęp: 12.11.2012]; 6) Regulamin Organizacyjny Archiwum Głównego Akt Dawnych w Warszawie z 1 grudnia 2008 roku, http://bip.ap.gov.pl/dokument.php [dostęp: 12.11.2012].

${ }^{30}$ Do najważniejszych przeszkód prawnych należy: 1) nadmiernie rozbudowana ochrona informacji niejawnej oraz ochrona osób publicznych, na podstawie ochrony danych osobowych, 2) ograniczone prawo dostępu do informacji publicznej, 3) brak prawnych i instytucjonalnych gwarancji wolności i praw obywatelskich, 4) bardzo rozbudowany katalog, obok ochrony informacji niejawnych, innych tajemnic ustawowo chronionych.

${ }^{31}$ Do najważniejszych przeszkód administracyjnych należy: 1) skomplikowana i długotrwała procedura uzyskiwania zgody na korzystanie pośrednie lub bezpośrednie z materiałów archiwalnych i informacji archiwalnej, 2) wydawanie decyzji niezgodnych z Kodeksem postępowania administracyjnego, np. bez niezbędnej podstawy prawnej, 3) wydawanie odmownych decyzji, np. na podstawie bardzo ogólnikowej interpretacji przepisów dotyczących ochrony informacji niejawnej.

32 Do najważniejszych przeszkód organizacyjnych należy: 1) przechowywanie ważnej części państwowego zasobu archiwalnego $w$ archiwach wyodrębnionych, 2) limitowanie miejsc dla użytkowników w pracowniach naukowych archiwów wyodrębnionych, 3) niedostateczny stan opracowania materiałów archiwalnych; zob. szerzej: J. Krochmal, Zasady uproszczonego opracowania zasobu archiwalnego, "Archeion” 2002, t. 104, s. 26-58; E. Rosowska, Stan opracowania zasobu archiwów państwowych, "Archeion” 2002, t. 104, s. 9-25. 
Ustawa archiwalna z 1983 roku utrzymała zasadę udostępniania materiałów archiwalnych w trybie zwykłym i wcześniejszym. Do celów naukowo-badawczych, publicystycznych ${ }^{33} \mathrm{i}$ innych materiały archiwalne moga być udostępniane po upływie 30 lat od ich wytworzenia, jeżeli nie narusza to prawnie chronionych interesów Rzeczypospolitej Polskiej i obywateli. W art. 17 ust. 2 ustawa ta przewidziała możliwość wcześniejszego udostępniania materiałów archiwalnych, o ile nie narusza to prawnie chronionych interesów państwa i obywatelỉis.

Procedura uzyskania dostępu do dokumentacji i materiałów archiwalnych nie jest sprzeczna z trybem dostępu do informacji publicznej. Ponadto warunkiem udostępnienia materiałów archiwalnych jest ich odtajnienie na podstawie Ustawy z dnia 5 sierpnia 2010 roku o ochronie informacji niejawnych, gdy zawierają informacje niejawne. Ochrona informacji niejawnych nie może być wyłącznie ważnym elementem ochrony bezpieczeństwa państwa polskiego i jego obywateli lub instytucji międzynarodowych, np. NATO, lecz również musi być zgodna z koncepcją społeczeństwa obywatelskiego i transparentnością sfery publicznej. Nie może także utrudniać lub uniemożliwiać dostępu do informacji publicznej i archiwalnej, z wyjątkiem przypadków niezbędnych $\mathrm{w}$ demokratycznym państwie prawa.

Udostępnienie materiałów archiwalnych zawierających informacje o osobach żyjących może nastąpić tylko wówczas, gdy ich udostępnienie nie przyniesie szkody moralnej lub materialnej osobom, których one dotyczą. Dla powyższych celów dostęp do materiałów archiwalnych następuje wyłącznie na pisemny wniosek o udostępnienie materiałów archiwalnych lub dokumentacji nie archiwalnej osoby prawnej lub fizycznej oraz po uzyskaniu zgody organu nadzorującego dane archiwum wyodrębnione. Decyzja o udostępnieniu jest podejmowana na podstawie: 1) przepisów prawa w zakresie: a) ochrony informacji niejawnej, b) archiwistyki, c) ochrony dóbr osobistych, d) szkolnictwa wyższego, 2) opinii właściwych merytorycznie jednostek organizacyjnych. Nie przewiduje się uzyskania dostępu do materiałów archiwalnych w trybie bez wnioskowym.

Zasób archiwów zakładowych i wyodrębnionych dzieli się na niejawny i jawny. Zasób niejawny jest przechowywany w wydzielonym i zabezpieczonym, zgodnie z przepisami o ochronie informacji niejawnych, pomieszczeniu kancelarii tajnej. Dostęp do zasobów zawierających informacje nie-

33 Dla publikacji materiału prasowego w rozumieniu przepisów Ustawy z dnia 26 stycznia 1984 roku - Prawo prasowe (Dz.U. Nr 5, poz. 24 ze zm.), z upoważnienia redakcji albo wydawcy.

34 Rozporządzenie Ministra Kultury i Dziedzictwa Narodowego z dnia 29 lipca 2008 roku w sprawie określenia szczególnych wypadków i trybu wcześniejszego udostępniania materiałów archiwalnych (Dz.U. Nr 156, poz. 970). 
jawne następuje zgodnie $\mathrm{z}$ przepisami o ochronie informacji niejawnych, a nie z ustawą archiwalną z 1983 roku. Do celów służbowych dokumentacja i materiały archiwalne mogą być udostępniane: 1) niezależnie od daty ich wytworzenia, 2) na miejscu lub wypożycza się je poza pomieszczenie archiwum (składnicy akt).

Podstawa prawna tworzenia baz danych i obiegu dokumentu elektronicznego $\mathrm{w}$ administracji i instytucjach publicznych, w tym również $\mathrm{w}$ archiwach państwowych, jest rozproszona, występuje zbyt duża liczba normatywów, a niektóre przepisy są nieskoordynowane i trudne do interpretacji. Prawo archiwalne zawiera przepisy wzajemnie sprzeczne, np. dotyczące zasad przekazywania materiałów archiwalnych, zarządzania i nadzoru nad narodowym zasobem archiwalnym. Przepisy są wyraźnie spóźnione w stosunku do wyzwań stających przed archiwami państwowymi. Brak okresów przejściowych na wdrożenie i dostosowanie przepisów do struktur organizacyjnych i systemów zarządzania opóźnia lub uniemożliwia wprowadzenie administracji elektronicznej oraz niezbędne przygotowanie pracowników. Nieopracowanie szczegółowych analiz dotyczących skutków finansowych nowych regulacji prawnych i rozwiązań systemowych naraża podmioty na ponoszenie znacznych kosztów bieżących związanych z funkcjonowaniem elektronicznego obiegu dokumentacji.

W archiwach państwowych bazy danych pojawiły się przed wprowadzeniem odpowiednich regulacji prawnych. Były odpowiedzią nie tylko na upowszechnienie się techniki mikrokomputerowej, lecz również na bieżące zadania w zakresie szybkiego dostępu do informacji archiwalnej, której nie zapewniały tradycyjne środki ewidencyjne. Problematyka informatyzacji archiwów polskich doczekała się licznych opracowań ${ }^{35}$. Bazy danych były tworzone przez archiwistów od początku lat dziewięćdziesiątych XX wie-

35 B. Ryszewski, Problemy komputeryzacji archiwów, Toruń 1994; H. Wajs, Archiwa wobec e-rzadu i społeczeństwa informacyjnego, [w:] Archiwa i archiwiści w dobie społeczeństwa informacyjnego. Pamiętnik IV Powszechnego Zjazdu Archiwistów polskich. Szczecin 12-13 września 2002 r., red. D. Nałęcz, Torun 2002, s. 55-64; A. Laszuk, Bazy danych w archiwach państwowych, [w:] Archiwa polskie wobec wyzwań XXI wieku. Pamiętnik III Powszechnego Zjazdu Archiwistów Polskich. Toruń 2-4 września 1997 r., t. I, red. D. Nałęcz, Radom 1997, s. 231-240; D. Nałęcz, Archiwa u progu ery informacji - bilans otwarcia, [w:] Archiwa i archiwiści..., s. 23-43; A. Laszuk, Stan informatyzacji archiwów państwowych, „Archeion” 2004, t. 107, s. 171-204; R. Kusyk, Digitalizacja archiwaliów. Dylematy prawne, "Archeion” 2004, t. 107, s. 285-300; T. Kantor, Przepisy kancelaryjno-archiwalne jednostki organizacyjnej wytwarzającej dokumenty elektroniczne, "Archeion” 2004, t. 107, s. 301-308; K. Wojsyk, Czy możliwe jest obecnie przygotowanie instrukcji kancelaryjnej uwzględniającej istnienie dokumentu elektronicznego?, "Archeion” 2004, t. 107, s. 309-324; D. Nałęcz, Rekomendacje Rady Europy, "Archeion” 2004, t. 107, s. 401-422; W. Sylwestrzak, XML a informatyzacja archiwów. Po co informatyzować archiwa?, "Archeion" 2004, t. 107, s. 205-218; A. Baniecki, ISAD (G) - Światowy system wielopoziomowego opisu materiałów archiwalnych. Wprowadzenie do zagadnienia, „Archeion” 2005, t. 108, s. 241-268. 
$\mathrm{ku}^{36}$. W końcu 2003 roku w archiwach państwowych było kilkaset lokalnych baz danych (najwięcej w Krakowie - 59 i Katowicach 53). Bazy danych można podzielić na: 1) ogólnopolskie, wprowadzone przepisami naczelnego dyrektora archiwów państwowych do obowiązkowego użycia, 2) lokalne, tworzone przez archiwa państwowe na własne potrzeby. Lokalne bazy danych były i są tworzone do realizacji zadań statutowych wynikających z przepisów metodycznych oraz zaspokajania potrzeb urzędowych administracji i instytucji publicznych oraz obywateli ${ }^{37}$. Nie opracowano kompleksowych programów ich konwersji do nowszego oprogramowania. Służą celom doraźnym, niekiedy krótkoterminowym. Nie ma koncepcji ich archiwizowania po utracie znaczenia praktycznego.

Nie udało się wprowadzić bazy lub baz danych, które zostałyby wykorzystane we wszystkich podmiotach państwowej sieci archiwalnej - archiwach zakładowych, wyodrębnionych i państwowych podległych naczelnemu dyrektorowi archiwów państwowych oraz instytucjach nie archiwalnych przechowujących materiały archiwalne tworzące państwowy zasób archiwalny. Utrudnia to opracowanie i wdrożenie kompleksowego systemu informacji o państwowym zasobie archiwalnym. Brak takiego systemu stanowi poważną przeszkodę dla efektywnego gromadzenia, zabezpieczania, udostępniania i zarządzania państwowym zasobem archiwalnym. Niestety, oprócz trudności organizacyjnych, technicznych i metodycznych, opracowanie takiego systemu uniemożliwia partykularna polityka informatyzacji prowadzona przez większość podmiotów tworzących państwową sieć archiwalną. Brakuje również koncepcji powstania zintegrowanego systemu teleinformatycznego, obejmującego twórcę materiałów archiwalnych, archiwum zakładowe, archiwum państwowe (wyodrębnione) i użytkownika. Bazy funkcjonowały wewnątrz danej instytucji lub miały co najwyżej charakter lokalny. Nie zwracano należytej uwagi na efektywność baz danych. Bardzo często nakład pracy na opracowanie i wpisanie danych był nieadekwatny do ich rzeczywistej efektywności. Brakowało i nadal brakuje skutecznych narzędzi ich badania pod tym względem.

Archiwiści państwowi pod koniec XX wieku musieli również pilnie rozwiązać problem masowego tworzenia baz danych i innych aplikacji $\mathrm{w}$ archiwach państwowych, który był związany z procesem informatyzacji instytucji publicznych i organów administracji publicznej. Od połowy lat dziewięćdziesiątych trwają prace nad zintegrowanym systemem informacji o narodowym zasobie archiwalnym oparte na międzynarodowym standar-

\footnotetext{
36 A. Laszuk, Stan informatyzacji..., s. 172-174.

37 A. Laszuk, Bazy danych..., s. 233; eadem, Stan informatyzacji..., s. 176-178.
} 
dzie opisu archiwalnego ISAD $(G)^{38}$, które jednak nie zostały jeszcze zakończone. Nie zostały sfinalizowane również działania na rzecz tworzenia systemów przystosowanych do międzynarodowej wymiany informacji archiwalnej oraz gromadzenia informacji z archiwów zagranicznych.

$\mathrm{W}$ archiwach państwowych podległych naczelnemu dyrektorowi archiwów państwowych wprowadzono obligatoryjnie kilkanaście bardzo ważnych baz danych. W 1996 roku wprowadzono bazę danych o nazwie System Ewidencji Zasobu Archiwalnego SEZAM - w ten sposób rozpoczął się proces tworzenia ogólnopolskich baz danych $\mathrm{w}$ archiwach państwowych podległych naczelnemu dyrektorowi archiwów państwowych ${ }^{39}$.

Do najważniejszych baz danych należą: 1) System Ewidencji Zasobu Archiwalnego SEZAM, który zawiera informacje o narodowym zasobie archiwalnym przechowywanym $\mathrm{w}$ archiwach państwowych, a także $\mathrm{w}$ wybranych instytucjach współpracujących; 2) Inwentarze Zespołów Archiwalnych IZA, zawierające scalone informacje $\mathrm{z}$ następujących baz danych: a) Inwentarze Zespołów Archiwalnych (IZA); b) inwentarze dokumentów wytworzonych do końca XVIII wieku (SCRINIUM); c) inwentarze dokumentacji technicznej (baza danych KITA - Komputerowa Informacja Techniczna); d) inwentarze dokumentacji kartograficznej - MAPY; e) inwentarze elektroniczne dokumentacji aktowej przygotowane w: Archiwum Głównym Akt Dawnych, Archiwum Akt Nowych oraz Archiwum Państwowym w Krakowie; 3) Program Rejestracji Akt Metrykalnych i Stanu Cywilnego PRADZIAD, który zawiera informacje o księgach metrykalnych i stanu cywilnego; 4) Ewidencje Ludności w Archiwaliach ELA, które zawierają informacje o sporządzanych na różne potrzeby i w różnych celach spisach ludności, we wszystkich ich fizycznych postaciach (ewidencje, wykazy, kartoteki itp.); 6) Zintegrowany System Informacji Archiwalnej ZoSIA, będący rozwiązaniem dla wszystkich polskich archiwów i instytucji posiadających zasoby archiwalne, który ma $\mathrm{w}$ przyszłości stanowić ogólnodostępny system informacji o polskich zbiorach archiwalnych; 7) FILMIK - rejestr mikrofilmów materiałów archiwalnych $\mathrm{z}$ archiwów zagranicznych; 8) MIKROFILM - mikrofilmy z zasobu własnego archiwów państwowych; 9) AFISZ - baza tematyczna do rejestracji plakatów; 10) SUMA - System Udostępniania Materiałów Archiwalnych; 11) RAP - rejestr Poszukiwań Archiwalnych; 12) NADZÓR - dane dotyczące archiwów zakładowych i ich kontroli 40 .

${ }^{38}$ A. Laszuk, Stan informatyzacji..., s. 178-180; G. Piątkowski, Komputeryzacja archiwów państwowych - wybrane problemy, "Teki Archiwalne” 2004, t. 8 (30), s. 87-100.

${ }^{39}$ A. Laszuk, System Ewidencji Zasobu Archiwalnego SEZAM, ",Archiwa, Biblioteki i Muzea Kościelne" 1998, t. 70, s. 91-98; eadem, Stan informatyzacji..., s. 180.

40 A. Laszuk, Stan informatyzacji..., s. 182-190. 
Informatyzacja archiwów państwowych, podobnie jak całego sektora publicznego, napotkała wiele trudności: prawnych, organizacyjnych, lokalowych i technicznych. Ważnym czynnikiem ograniczającym zastosowanie informatyki w archiwistyce byli i są pracownicy, którzy w części należą do grupy obywateli wykluczonych informatycznie, a ponadto obawiają się o swoje stanowiska i przyzwyczajeni są do tradycyjnych metod pracy. Do nowych metod nie została przystosowana ani teoria archiwalna, ani metodyka pracy archiwalnej; dotyczyło zarówno postępowania z dokumentacją elektroniczną i mieszaną, jak i wspomagania tradycyjnej archiwistyki przez narzędzia informatyczne.

Wprowadzenie baz danych lub zintegrowanego systemu teleinformatycznego wymagało i nadal wymaga spełnienia następujących warunków: 1) analizy, uporządkowania i dostosowania obowiązujących przepisów archiwalnych dotyczących twórców dokumentacji i materiałów archiwalnych wchodzących w skład państwowego zasobu archiwalnego, archiwów zakładowych i składnic akt, archiwów państwowych i wyodrębnionych, bibliotek i muzeów, instytucji z powierzonym zasobem archiwalnym oraz użytkowników dokumentacji, materiałów archiwalnych i informacji archiwalnej do postępowania $\mathrm{z}$ dokumentacją i materiałami archiwalnym $\mathrm{w}$ postaci elektronicznej, również w formie baz danych; 2) analizy, uporządkowania i dostosowania obowiązujących przepisów metodycznych lub opracowania nowych dotyczących zasad postępowania z dokumentacją i materiałami archiwalnym w postaci elektronicznej lub odwzorowania cyfrowego dokumentacji i materiałów archiwalnych papierowych i poza aktowych; 3) przekonania twórców, archiwistów i użytkowników, że elektroniczne zarządzanie dokumentacją i materiałami archiwalnym może nie tylko wpłynąć na szybkość dotarcia do informacji archiwalnej w nich zawartej, lecz także znacząco poprawić efektywność działalności archiwalnej.

Panowało złudne przekonanie, że informatyzacja będzie skutecznym środkiem na wszystkie trudności w działalności archiwalnej, np. na bardzo duże zaległości w opracowaniu materiałów archiwalnych, trudności lokalowe i magazynowe archiwów, niszczenie dokumentacji i materiałów archiwalnych papierowych - tzw. „kwaśny papier”, brak nowoczesnych środków ewidencyjno-informacyjnych, duże zaległości w zakresie reprografii zabezpieczających państwowy zasób archiwalny i inne. Tymczasem bez rozwiązania kluczowych problemów archiwistyki polskiej efektywne wykorzystanie informatyki, w tym również baz danych, było i pozostaje niemożliwe.

Pracownicy komórek organizacyjnych tworzących dokumentację, archiwiści zakładowi, pracownicy składnic akt, archiwiści państwowi nie byli przygotowani do tworzenia kompatybilnych baz danych za pomocą uniwersalnego i powszechnie dostępnego oprogramowania. Brakowało i bra- 
kuje współpracy twórców dokumentacji, również z archiwów zakładowych, z archiwami państwowymi (wyodrębnionymi) oraz użytkownikami archiwów nad wykorzystaniem baz danych na kolejnych etapach tworzenia dokumentacji, do których należą: 1) twórcy dokumentacji, 2) komórki organizacyjne i archiwum zakładowe, 3) archiwa wyodrębnione, 4) archiwa państwowe podległe naczelnemu dyrektorowi archiwów państwowych. Dominowały działania doraźne i nieskoordynowane. Tworzono bazy danych dla dokumentacji, z której najczęściej korzystali użytkownicy publiczni i niepubliczni, np. akt stanu cywilnego, ewidencja ludności i inne.

Administracja rządowa nie określiła standardów tworzenia zintegrowanych systemów teleinformatycznych ani celów i metody ich tworzenia, nie zabezpieczyła środków finansowych - brak długofalowej strategii ich finansowania, brak wsparcia dla poszczególnych podmiotów i przekazywania doświadczeń z wdrażania systemów teleinformatycznych w Ministerstwie Spraw Wewnętrznych.

Uporządkowania powyższych niedociągnięć nie ułatwia brak polityki informatyzacji Rzeczypospolitej Polskiej, tworzenia e-administracji i społeczeństwa informacyjnego, pomimo opracowania strategicznych dokumentów.

Nieprzygotowanie użytkowników archiwów państwowych utrudnia użytkowanie baz danych. By efektywnie z nich korzystać, należy znać terminologię archiwalną, zasady rozmieszczenia zasobu archiwalnego, zasady ewidencji materiałów archiwalnych i inne. Bazy danych, niestety, były tworzone dla archiwistów państwowych, a nie dla użytkowników archiwów. Dodatkowymi utrudnieniami są: brak nowoczesnej formy graficznej, systemu pomocy i kompatybilności z najnowszymi narzędziami informatycznymi. Zintegrowany system informatyczny mógłby ułatwić użytkownikowi dostęp do informacji rozproszonych po instytucjach przechowujących materiały archiwalne: archiwach zakładowych, składnicach akt, archiwach wyodrębnionych, archiwach państwowych, bibliotekach, muzeach, podmiotach $\mathrm{z}$ powierzonym zasobem archiwalnym $\mathrm{i}$ archiwach niepaństwowych.

Warunkiem prawidłowego funkcjonowania dokumentu elektronicznego $\mathrm{w}$ organach publicznych są nie tylko określone zasady jego obiegu, lecz również archiwizacji. Dlatego oprócz prawnych aspektów funkcjonowania dokumentu elektronicznego, jego struktury i formatu zapisu, musiały zostać określone także zasady kształtowania, gromadzenia i przejmowania dokumentów elektronicznych tworzących państwowy zasób archiwalny.

Bazy danych, pomimo licznych braków, o których mowa powyżej, odegrały ważną rolę $\mathrm{w}$ informatyzacji archiwów państwowych i upowszechnieniu informacji archiwalnej wśród obywateli. Nadal niezbędne są działania na rzecz zwiększenia ich efektywności i społecznego wykorzystania 
w ramach realizacji koncepcji rozwoju globalnego społeczeństwa informacyjnego. W przeciwnym wypadku archiwa państwowe i ich użytkownicy zostaną wykluczeni informatycznie, gdy dotychczasowe rozwiązania $\mathrm{w}$ zakresie wdrożenia administracji elektronicznej i zarządzania dokumentacją elektroniczną pozostaną na marginesie ogólnoświatowego procesu informatyzacji.

\section{BIBLIOGRAFIA}

Aleksandrowicz T.R., Komentarz do ustawy o dostępie do informacji publicznej. Stan prawny na 2 stycznia 2008 roku, Warszawa 2008.

Archiwa. Przepisy prawne (2000-2007), wybór i oprac. R. Galuba, Poznań 2007.

Baniecki A., ISAD (G) - Światowy system wielopoziomowego opisu materiatów archiwalnych. Wprowadzenie do zagadnienia, "Archeion” 2005, t. 108.

Beagrie N., Narodowe inicjatywy w zakresie przechowywania cyfrowego, "Archeion" 2004, t. 107.

Janowski W., Archiwa państwowe wobec problemu akt niejawnych, „Teki Archiwalne” 2000, t. 5 .

Kantor T., Przepisy kancelaryjno-archiwalne jednostki organizacyjnej wytwarzajacej dokumenty elektroniczne, "Archeion” 2004, t. 107.

Ketelaar E., „Cyfrowe życie” w archiwum dla ludzi, „Archeion” 2004, t. 107.

Krochmal J., Zasady uproszczonego opracowania zasobu archiwalnego, "Archeion” 2002, t. 104.

Kusyk R., Digitalizacja archiwaliów. Dylematy prawne, „Archeion” 2004, t. 107.

Laszuk A., Bazy danych w archiwach państwowych, [w:] Archiwa polskie wobec wyzwań XXI wieku. Pamiętnik III Powszechnego Zjazdu Archiwistów Polskich. Toruń 2-4 września 1997 r., t. I, red. D. Nałęcz, Radom 1997.

Laszuk A., Stan informatyzacji archiwów państwowych, „Archeion” 2004, t. 107.

Laszuk A., System Ewidencji Zasobu Archiwalnego SEZAM, "Archiwa, Biblioteki i Muzea Kościelne" 1998, t. 70.

Nałęcz D., Archiwa u progu ery informacji - bilans otwarcia, [w:] Archiwa i archiwiści w dobie spoteczeństwa informacyjnego. Pamiętnik IV Powszechnego Zjazdu Archiwistów polskich. Szczecin 12-13 września 2002 r., red. D. Nałęcz, Torun 2002.

Nałęcz D., Rekomendacje Rady Europy, „Archeion” 2004, t. 107.

Piątkowski G., Komputeryzacja archiwów państwowych - wybrane problemy, "Teki Archiwalne" 2004, t. 8 (30).

Plan działań na rzecz rozwoju elektronicznej administracji (eGovernment) na lata 2005-2006, Warszawa 2004.

Rosowska E., Stan opracowania zasobu archiwów państwowych, „Archeion” 2002, t. 104.

Ryszewski B., Problemy komputeryzacji archiwów, Torun 1994.

Sagan S., Prawo konstytucyjne Rzeczypospolitej Polskiej, Warszawa 2001.

Schmidt K., Prace przygotowawcze do archiwizacji dokumentów elektronicznych - doświadczenia australijskie i brytyjskie, "Archeion” 2004, t. 107.

Strategia kierunkowa rozwoju informatyzacji Polski do roku 2013 oraz perspektywiczna prognoza transformacji społeczeństwa informacyjnego do roku 2020, Warszawa 2005. 
Sylwestrzak W., XML a informatyzacja archiwów. Po co informatyzować archiwa?, „Archeion" 2004, t. 107.

Szaniawski K., Kościelny T., Ustawa o podpisie elektronicznym: komentarz, Kraków 2003.

Taradejna R. i M., Dostęp do informacji publicznej a prawna ochrona informacji dotyczacych działalności gospodarczej, społecznej i zawodowej oraz życia prywatnego, Torun 2003.

Wajs H., Archiwa wobec e-rzadu i społeczeństwa informacyjnego, [w:] Archiwa $i$ archiwiści $w$ dobie społeczeństwa informacyjnego. Pamiętnik IV Powszechnego Zjazdu Archiwistów polskich. Szczecin 12-13 września 2002 r., red. D. Nałęcz, Torun 2002.

Wojsyk K., Czy możliwe jest obecnie przygotowanie instrukcji kancelaryjnej uwzględniającej istnienie dokumentu elektronicznego?, "Archeion" 2004, t. 107.

Wyrozumska E., Elektroniczne oświadczenie woli w ustawie o podpisie elektronicznym i po nowelizacji kodeksu cywilnego, „Przegląd Prawa Handlowego” 2003, nr 8. 